\title{
Dr. Ivo Pilar u hrvatskom povijesnom vegetarijanskom mozaiku
}

Krešimir Belošević, ing. TPH

\author{
Izvorni znanstveni rad \\ Primljeno: 28.lipnja 2021. \\ UDK 929Pilar, I.:613 \\ $631.261(497.5)(091)$ \\ doi: $10.5559 /$ pi. 16.31 .04
}

\begin{abstract}
U radu se donose rezultati nastavka istraživanja uloge dr. Ive Pilara na polju hrvatskog vegetarijanstva. Novi momenti vezani su prvenstveno uz analizu arhivske građe sačuvane $u$ arhivskom fondu Hrvatsko vegetarsko društvo u Državnom arhivu u Zagrebu, a u istraživanju je korištena i druga građa koja se čuva u istom arhivu te u Hrvatskome državnom arhivu i Nacionalnoj $i$ sveučilišnoj knjižnici u Zagrebu. Rad se bavi ulogom dr. Pilara kao prvog predsjednika Vegetarskoga društva u Zagrebu i njegovim aktivnim sudjelovanjem u organiziranju vegetarijanaca na hrvatskom prostoru. Govori se i o prigodama u kojima je Pilar svoja razmišljanja o vegetarijanskoj prehrani javno iznosio u susretima s raznim društveno-političkim ličnostima, te na predavanjima o temama iz područja vegetarijanstva koja je u više navrata održao u raznim društvima.
\end{abstract}

Ključne riječi: dr. Ivo Pilar, vegetarijanstvo, Vegetarsko društvo

Dr. Ivo Pilar, pravnik i ekonomist, školovan u Zagrebu, Beču i Parizu, koji je kao odvjetnik prvo djelovao u Bosni i Hercegovini a potom u Zagrebu, tijekom života pokazivao je interes za brojna područja, pa ga možemo uvrstiti u red geopolitičara, pisaca, planinara, sociologa. ${ }^{1}$ Između ostalog, Pilara je zanimalo i vegetarijanstvo te je bio jedan od istaknutih vegetarijanaca u početcima organiziranog vegetarijanskog pokreta u Hrvatskoj. ${ }^{2}$

1 O životu i djelovanju Ive Pilara vidi: Tomislav JONJIĆ, Ivo Pilar. Pisac, političar, ideo$\log$ (1898.-1918.), Zagreb, AGM, 2020., te neobjavljenu doktorsku disertaciju istoga autora, Ivo Pilar kao politički ideolog, Hrvatski studiji Sveučilišta u Zagrebu, 2015. i ondje korištenu literaturu. Djelomičnu bibliografiju radova dr. Ive Pilara i djela o njemu vidi na: https://www.pilar.hr/2008/11/literatura-o-ivi-pilaru/ i https://www.pilar.hr /2017/11/asopis-pregled-sadraja/\#br27-28 (pristupljeno 17. 5. 2021.), dalje Bibliografija radova dr. Ive Pilara.

2 O ulozi dr. Ive Pilara na području vegetarijanstva vidi: Krešimir BELOŠEVIĆ, "Dr. Ivo Pilar - prvi predsjednik Vegetarskog društva (Počeci organiziranog vegetarijanskog pokreta u Hrvatskoj)،, Pilar. Časopis za društvene i humanističke studije, Zagreb, 2006., god. 1, br. 1 (1), 109-116. 
Istraživanje Pilarova djelovanja na polju vegetarijanstva dio je većeg istraživanja o povijesti vegetarijanstva u Hrvatskoj koje provodim više godina pod radnim naslovom Hrvatski povijesni vegetarijanski mozaik. ${ }^{3}$ Osobno iskustvo vegetarijanstva dr. Pilar često je predstavljao u predavanjima i susretima, a pisao je i dnevnik koji je djelomično sačuvan u njegovoj rukopisnoj ostavštini. Obitelj dr. Pilara donirala je većinu te rukopisne ostavštine Institutu društvenih znanosti Ivo Pilar 26. studenoga 2009. godine. Ostavština dr. Ive Pilara čuva se u Zbirci rukopisa i starih knjiga u Nacionalnoj i sveučilišnoj knjižnici u Zagrebu u trajnoj pohrani. ${ }^{4}$ Tijekom života Pilar je objavio više knjiga i radova različite tematike te sudjelovao u raznim događanjima diljem Europe. Umro je 3. rujna 1933. godine u Zagrebu, gdje je pokopan u obiteljskoj grobnici na zagrebačkom groblju Mirogoju. 5

\section{Dr. Ivo Pilar vegetarijanac}

Dr. Ivo Pilar postao je vegetarijanac oko 1904. godine. To se može zaključiti iz susreta dr. Isidora Kršnjavoga6 ${ }^{6}$ dr. Pilara početkom lipnja 1918. godine. Dr. Kršnjavi u svojim memoarskim zapisima opisuje taj susret. Dr. Pilar mu je izložio ideju o osnivanju nove političke stranke u Bosni. Želja dr. Pilara bila je da dr. Kršnjavi uz sarajevskog nadbiskupa mons. Josipa Stadlera sudjeluje u osnivanju te stranke. U daljnjoj raspravi o toj temi dr. Pilar je objašnjavao ciljeve nove stranke te zapravo održao predavanje o potrebi preo-

3 Istraživanje radnog naslova Hrvatski povijesni vegetarijanski mozaik temelji se na arhivskoj građi, periodičnim izdanjima i knjigama koje se čuvaju u Hrvatskome državnom arhivu, Državnom arhivu u Zagrebu i Nacionalnoj i sveučilišnoj knjižnici u Zagrebu. Državni arhiv u Zagrebu čuva arhivsku građu vezanu uz organizirano vegetarijanstvo u arhivskom fondu HR-DAZG-792 - Hrvatsko vegetarsko društvo, dalje HVD.

${ }^{4}$ Nacionalna i sveučilišna knjižnica u Zagrebu uz Ostavštinu dr. Ive Pilara čuva i časopis Vegetarizam, Glasnik Vegetarskog društva u Zagrebu (pod sig. 88.392 adl. 3). Tijekom 2019. godine Ostavštini je pridodana korespondencija Ive Pilara s češkim povjesničarom i sociologom Janom Peiskerom, autografi Pilarovih tekstova i osobni Pilarovi dokumenti. Više vidi na https://www.nsk.hr/zbirci-rukopisa-i-starih-knjiga-nsk-pridodanaostavstina-ive-pilara/ (pristupljeno 26. 10. 2021.). O ostavštini dr. Ive Pilara pohranjenoj u NSK-u, Zagreb, više vidi u tekstu Irene Galić BEŠKER, "Rukopisna ostavština Ive Pilara u Nacionalnoj i sveučilišnoj knjižnici u Zagrebu", Glas NSK. Časopis Nacionalne i sveučilišne knjižnice u Zagrebu, Zagreb, 2020., god. 6, br. 16, 40-42.

5 Srećko LIPOVČAN, "Dr. Ivo Pilar (1874.-1933.): Život i djelo (Nacrt)", Pilar. Časopis za društvene i humanističke studije, Zagreb, 2006., god. 1, br. 1(1), 11-19. O životu dr. Ive Pilara vidi i već spomenutu knjigu Tomislava JONJIĆA Ivo Pilar. Pisac, političar, ideolog (1898.-1918.)

6 O Isi Kršnjavom više vidi u leksikografskoj odrednici Olga Maruševski, Višnja Flego, "Kršnjavi Iso (Isidor, Izidor) (Našice 22. travnja 1845. — Zagreb 3. veljače 1927.) «, Hrvatski biografski leksikon, sv. 8 (Kr-Li), gl. ur. Trpimir Macan, Zagreb, Leksikografski zavod Miroslav Krleža, 2013., 252-257. 
brazbe hrvatskoga naroda. Pišući o tome kako mu je Pilar objašnjavao da nova stranka treba preobraziti hrvatski narod u gospodarskom, etičkom, etničkom i političkom pogledu, Kršnjavi navodi i da mu je Pilar ispričao "kako je $s$ trideset godina bio bolestan i slab, nesposoban za rad, i kako je izmijenio svoj način življenja time što je postao strogi apstinent i vegetarijanac". Na temelju toga svoga iskustva Pilar je objašnjavao Kršnjavom da tako "i naš narod mora živjeti trezveno i umjereno da bi gospodarski i etički ojačao".7

Nepunih deset godina poslije, početkom veljače 1913. godine, dr. Ivo Pilar posjetio je Beč. U Beču se susreo s austrijskim političarem Josephom M. Baernreitherom. ${ }^{8}$ Susret je Baernreither opisao u svojoj knjizi Fragmente eines politischen Tagebuches: Die südslawische Frage und Österreich - Ungarn vor dem Weltkrieg. U tom svojevrsnom dnevniku između ostalog je zapisao: "Danas sam imao dugi razgovor sa dr. Ivom Pilarom (1874-1933) advokatom iz Tuzle; on je zet odjelnoga pretstojnika Šeka, katolički Hrvat, naučenjak, vegeterijanac, vrlo apstraktan, mnogo mudruje, ali vrlo ozbiljan čovjek na koga je utjecala njemačka znanost. "9 I iz ovog citata vidi se da je Pilar u svakoj prilici isticao svoje vegetarijanstvo.

\section{Vegetarijanske ideje u knjigama dr. Ive Pilara}

Ivo Pilar je vegetarijanske stavove iznosio i u svojim knjigama. To vidimo i u njegovu najpoznatijem djelu, knjizi Die südslawische Frage und der Weltkrieg. Überisichtiche Darstellung des Gesamt-Problems, koju je izdao pod pseudonimom L. v. Südland u Beču 1918. godine. U njemu u dijelu u kojem govori o bogumilima piše: "Signaculum oris, daß man sich des Fleischgenusses ebenso wie jeder tierischen Nahrung enthalten müsse, denn diese sei im erhöhten Maße das Werk des Teufels, da sie durch Beischlaf erzeugt wurde. ${ }^{10}$

\footnotetext{
7 Više vidi u: Iso KRŠNJAVI, Zapisci iza kulisa hrvatske politike, priredio dr. Ivan Krtalić, Zagreb, Izdavačko knjižarska radna organizacija Mladost, 1986., knj. 2, 796-797.

8 Joseph Maria Baernreither (Prag 12. travnja 1845. - Teplice 19. rujna 1925.), austrougarski sudac i političar. O austrijskom političaru Josephu M. Baernreitheru više vidi na https://hemu.lzmk.hr/Natuknica.aspx?ID=3752, https://hemu.lzmk.hr/Natuknica.aspx? ID=3753, i https://www.biographien.ac.at/oebl/oebl_B/Baernreither_Josef-Maria_1845 _1925.xml (pristupljeno 9. 4. 2021.).

9 Više vidi u Joseph M. BAERNREITHER, Fragmente eines politischen Tagebuches: Die südslawische Frage und Österreich - Ungarn vor dem Weltkrieg, ur. Joseph Redlich, Berlin, Verlag für Kulturpolitik, 1928. Susret je prema toj knjizi opisao Ante MALBAŠA u svojoj knjizi Bosansko pitanje i Austro-Ugarska u svijetlu političkog dnevnika J. M. Baernreithera, Sarajevo, Bosanska pošta, 1933., 62.

10 Više vidi u L. v. Südland, Die südslawische Frage und der Weltkrieg. Uebersichtliche Darstellung des Gesamt-Problems, Beč, Manzsche K. U. K. Hof-, Verlags- U. Universitäts Buchhandlung, 1918., 161. Izdanje iz 1918. godine dostupno je na: https://archive. org/details/diesdslawische00pilauoft (pristupljeno 9. 4. 2021.).
} 
Prijevod ove knjige na hrvatski objavljen je 1943. pod naslovom Južnoslavensko pitanje: prikaz cjelokupnog pitanja. Tekst o bogumilima na hrvatskom prema ovom izdanju glasi "Signaculum oris značio je, da se treba čuvati svakog uživanja mesa i svake životinjske hrane, jer je ona u povećanom stupnju djelo sotone, budući da je nastala coitusom. «11

U djelima dr. Ive Pilara uz istraživanja političke naravi nalazimo i svjedočanstva da ga je zanimala i makrobiotika. Nakon proučavanja raznih filozofskih pitanja, dr. Pilar u Zagrebu 1922. godine tiska knjigu pod naslovom Borba za vrijednost svoga "Ja". Pokušaj filozofije slavenskog individualizma. U poglavlju "Metode afirmacije života" između ostalog piše: "Afirmacija života sama je sobom jedan problem u životu, u formi makrobiotike, u nastojanju oko produženja života." Pilar zaključuje riječima: "Makrobiotika je dakle jedna važna znanost, jer ne samo pojedinac sa svoga subjektivnoga stanovišta, sa svoje težnje za afirmacijom života, nego i općenost ima interesa na što dužem životu svojih članova." ${ }^{12}$

\section{Predavanja dr. Ive Pilara u kojima se dotiče i teme vegetarijanstva}

Osim u knjigama dr. Pilar široj je javnosti predočio rezultate svojih istraživanja i tijekom predavanja, a u njima se također doticao vegetarijanstva, bilo usputno, bilo kao glavne teme kojom se nekom prilikom bavio. Početkom 1927. godine više puta je predavao u Sociološkom društvu na temu "Bogomilstvo kao religijozno-povjestni te kao socijalni i politički problem». Tijekom predavanja dr. Pilar spominje prehrambene navike bogumila, koji su bili vegetarijanci. Tako između ostalog piše: "Daljnji osnov bogomilske etike bio je strogi i asketski način prehrane. Oni su bili strogi vegetarijanci, koji nisu smjeli jesti mesa, jaja, ni bijeloga smoka (mliječnih proizvoda), kao ni ičega od žive životinje. Iznimku je činila riba, koje je užitak bio dozvoljen, jer kako su oni držali, riba se ne množi prilegom. Posljedica ovoga načina

\footnotetext{
11 Deset godina poslije Pilarove smrti objavljen je prijevod njegove knjige Južnoslavensko pitanje: prikaz cjelokupnog pitanja. Knjiga je tiskana u izdanju Matice hrvatske, Zagreb, 1943. godine. Preveo ju je Fedor Pucek. Citirani tekst o bogumilima nalazi se na stranici 90. Sljedeće 1944. godine kod istog izdavača tiskano je i njemačko izdanje knjige, L. v. SÜDLAND, Die südslawische Frage und der Weltkrieg. Übersichtliche Darstellung des Gesamt-Problems. Hrvatski prijevodi izdani su i 1990. godine u Varaždinu, 2018. godine u Zagrebu/Sydneyu i u Zagrebu 2021. godine.

12 Usp. Ivo PILAR, Borba za vrijednost svoga "Ja“. Pokušaj filozofije slavenskog individualizma, Zagreb, Naklada St. Kugli, 1922., 242-243. Za ovo poglavlje dr. Pilar je proučio knjige Christopha Wilhelma HUFERLANDA, Makrobiotik oder die Kunst, das menschliche Leben zu verlängern, V. izdanje, Beč, 1890. i Frana Srećka GUNDRUMA ORIOVČANINA, O produljenju života, Zagreb, izdanje Braća Kralj, 1907.
} 
prehrane bila je kultura suhoga voća u Bosni i zapadnoj Srbiji, koju poznamo naposeb po glasovitim bosanskim suhim šljivama. Ali osim šljiva suši se u Bosni svaka voćka, jabuka, kruška, trešnja, breskva, oskoruša etc. Ovo je sve nepreporno bogomilskoga podrijekla, jer bogomili preko zime nisu imali druge hrane, nego suho voće i kruh.«13 Zanimljivost je da je to Pilarovo predavanje koristio u svom istraživanju sarajevski teolog, etnolog, povjesničar, novinar Mehmed Handžić. ${ }^{14}$ On je 1940. godine u Sarajevu tiskao knjižicu Islamizacija Bosne i Hercegovine i porijeklo bosansko-hercegovačkih Muslimana. U tom prikazu Handžić između ostalog o bogumilima piše: "Pravi bogumili su bili nemrsni ljudi, dakle vegetarijanci“, te dalje ističe: "Dr Pilar drži, da je običaj mnogo sušenja voća, osobito bosanske suhe šljive, ostatak bogomilske kulture, jer preko zime hranili su se bogomili kruhom i suhim voćem. 15

Razne teme s naglaskom na vegetarijanstvo obradio je dr. Pilar u predavanjima u različitim društvima, u Vegetarskom i Sociološkom društvu, te kao Zmaj Tuzlanski (Solski) i u Družbi "Braća Hrvatskoga Zmaja". Ondje je izlagao na temu "Znanstvena osnova savremenog vegetarijanstva". Podatak o tom predavanju nalazi se u Hrvatskome državnom arhivu u arhivskom fondu Družba Braća Hrvatskoga Zmaja. ${ }^{16} \mathrm{Na}$ istome mjestu čuva se još jedan za povijest vegetarijanstva u Hrvatskoj važan dokument - letak što ga je Vegetarsko društvo uputilo sugrađanima pod naslovom "Vaše zdravlje je u

13 Predavanja o bogumilima dr. Pilar je održao 10. veljače i 10. ožujka 1927. godine, a tiskana su 1929. u Zagrebu. Predavanje je ponovno tiskano 2007. godine u Pilar. Časopis za društvene i humanističke studije, Zagreb, 2007., god. 2, br. 4 (2), 121-145.

14 Mehmed Handžić (Sarajevo, 16. prosinca 1906. - Sarajevo, 29. srpnja 1944.), teolog, etnolog, povjesničar i novinar završio je u Sarajevu osnovnu školu i gimnaziju, a diplomirao je na sveučilištu Al-Azhar u Kairu 1931. godine. Vojsku je služio u Vojnoj bolnici u Sarajevu. Bio je nastavnik u Gazi Husrev-begovoj medresi (visoka islamska škola), a od 1937. godine upravitelj je i knjižničar Gazi Husrev-begove knjižnice. Bio je predsjednik El-Hidaje (profesionalne udruge islamskih klerika) od 1939. i urednik istoimenih novina. Iste godine postaje nastavnik na Višoj islamskoj šerijatsko-teološkoj školi u Sarajevu gdje je predavao tumačenje Kurana, te osnove i filozofiju šerijatskog prava. Tijekom svog kratkog života napisao je više knjiga jezične, pravne i vjerske tematike. Više vidi na https://preporod.com/index.php/sve-vijesti/magazin/sjecanja/item/4438mehmed-ef-handzic-obnovitelj-i-prosvjetitelj (pristupljeno 25. 10. 2021.).

15 Handžićeva knjižica može se pregledati na https://digital.bgs.ba/islamizacija-bosnei-hercegovine-i-porijeklo-bosansko-hercegovackih-muslimana-mehmed-h-handzic/, 10 (pristupljeno 27. 5. 2021.).

16 HR-HDA-635-2, kut. 28, Personalia Pa-Pi. U ovoj kutiji nalazi se personalni dosje dr. Ive Pilara s raznim dokumentima. Dokument u kojem doznajemo za predavanje sadrži obavijest kojom se uime "Braće hrv. zmaja" pozivaju novinska uredništva da obavijeste javnost kako će na tjednom sastanku 15. listopada (1930.?) dr. Ivo Pilar, Zmaj Solski, predavati o temi "Znanstvena osnova savremenog vegetarijanstva". 
opasnosti!ı i u čijoj je pripremi dr. Pilar također sudjelovao. Tim letkom vegetarijanci su savjetovali sugrađane da smanje što više količinu soli i mirodija u hrani, kao i da u prehranu uvrste više voća. Letak zaključuju riječima: "Ispravno hranjenje najbolje je liječenje, najbolje sredstvo da se svježina tijela očuva do krajnih granica. «17

Početkom veljače 1932. godine u prostorijama Vegetarskog društva dr. Pilar je uz dr. Milicu Bogdanović i dr. Ivu Hengstera predavao na temu "Općenito o vegetarizmu" pred 76 slušatelja. ${ }^{18}$ Početkom sljedeće godine, također u prostorijama Društva, izlagao je na teme "Povijest vegetarizma" i "Ima li poteškoće u vegetarskom načinu života?"19 Dana 14. ožujka 1933., odgovarajući na pitanje "Ima li poteškoća u vegetarskom načinu života?", dr. Pilar je predavao na temu "Opasnosti vegetarizma 20

Osim spomenutih predavanja na temu vegetarijanstva dr. Pilar održao je i više drugih predavanja u Sociološkom društvu o raznim temama: o Georgesu Sorelu, francuskom filozofu, krizi suvremene državnosti, islamu, svjetskoj politici, a bavio se i drugim temama. ${ }^{21}$

\section{Dr. Ivo Pilar kao predsjednik Vegetarskoga društva}

Osim teorijskim razmišljanjima dr. Pilar je mnogo vremena posvetio organiziranju praktičnog vegetarijanstva. ${ }^{22}$ Potkraj lipnja 1928. godine sastao se s jedanaest istomišljenika u Privatnoj menzi Mary i Ljudevita Frankovića u Dalmatinskoj ulici 5 u Zagrebu na osnivačkoj skupštini Vegetarskoga društva.23 Uz dr. Pilara nazočili su joj dr. Milica Bogdanović, ${ }^{24}$ Mary i Ljudevit Franko-

17 „Vaše zdravlje je u opasnosti“, HR-HDA-635-2, kut. 28, Personalia Pa-Pi.

18 HVD sig. 1, Zapisnik V. redovne glavne skupštine Vegetarskog društva u Zagrebu od 15. prosinca 1932. godine.

19 Predavanje "Povijest vegetarizma" dr. Ivo Pilar održao je 10. siječnja 1933. godine pred 76 slušatelja u Vegetarskoj blagovaoni.

$20 \mathrm{O}$ "Opasnostima vegetarizma" predavao je pred 37 slušatelja. HVD sig. 1, Zapisnik VI. redovne skupštine Vegetarskog društva u Zagrebu od 20. travnja 1933.

21 Detaljniji popis predavanja dr. Ive Pilara vidi u Bibliografiji radova dr. Ive Pilara.

22 Pilarova uloga u Vegetarskom društvu opširno je prikazana u: Krešimir BELOŠEVIĆ, "Dr. Ivo Pilar - prvi predsjednik Vegetarskog društva (Počeci organiziranog vegetarijanskog pokreta u Hrvatskoj)“, Pilar. Časopis za društvene i humanističke studije, Zagreb, 2006., god. 1, br. 1 (1), 109-116.

23 Početkom 20. stoljeća postojale su u Zagrebu privatne vegetarijanske menze - Mary i Ljudevita Frankovića u Dalmatinskoj 5 i Ane Smrekal na Jelačićevom trgu 2, I. kat, dvorišno krilo. U njima su se okupljali na sastancima i obrocima vegetarijanci. Više vidi u zapisnicima Hrvatskoga vegetarskog društva

$24 \mathrm{O}$ dr. Milici pl. Bogdanović više vidi u leksikografskoj odrednici Dunja Detoni-Dujmić, Bogdanović, Milica (Linz. Austrija, 29. ožujka 1892. — Beograd, 2. veljače 1973.), Hrvatski biografski leksikon, sv. 2 (Bj-C), Jugoslavenski leksikografski zavod Miroslav Krleža, 1989., 74. 
vić, Cecilija i Edo Horn, Valerija Mayerhoffer, Milena Šišić,25 Jelisava (Liza, Jiza) Vavra, ${ }^{26}$ Martin Friščić, dr. Ivo Hengster ${ }^{27}$ i Marko Werner ${ }^{28}$. Dr. Pilar je iskoristio europska iskustva stečena tijekom školovanja i izradio pravila zagrebačkog Vegetarskog društva prema bečkom uzoru. Na osnivačkoj sjednici Društva izabran je za njegova prvog predsjednika. Uz njega prvu upravu Društva činili su dr. Milica Bogdanović — potpredsjednica, odbornici Ljudevit Franković, Martin Friščić, dr. Ivo Hengster, Vlado Majstorović, prof. Valerija Mayerhoffer, prof. Jelisava Vavra i Marko Werner. Članovi nadzornog odbora bili su Edo Horn, Jelisava Vavra, Vjekoslav Smetko i Olga Ulčakar. Uime Privremenog odbora pravila su tog dana potpisali dr. Bogdanović, M. Werner i Lj. Franković. ${ }^{29}$ Pravila je odobrio veliki župan Zagrebačke oblasti 20. srpnja 1928. godine pod brojem 44.665-1928.30

Organiziranje Vegetarskog društva nastavilo se početkom listopada 1928. godine. Na Prvoj odborničkoj sjednici Društva predsjednik dr. Pilar pozdravio je prisutne te ih pozvao na rad i predložio da prva dužnost Društva bude izrada Popisa vegetaraca u Zagrebu. Svim članovima stavljeno je u zadatak da rade na animiranju novih članova te da se u Menzi izvjesi poziv svim gostima vegetarijancima da se jave vlasniku menze. Tog dana na sjednici se raspravljalo i o pisarničkim potrebama, odnosno nabavi blagajne, knjige za-

25 Milena Šišić r. Mihalović (1876.-1965.), teozofkinja i vegetarijanka, supruga povjesničara Ferde Šišića. Izabrana je za drugu predsjednicu Vegetarskoga društva u Zagrebu na Glavnoj skupštini Vegetarskog društva održanoj u pisarnici dr. Pilara 22. svibnja 1929. godine. Bila je predsjednica do VI. redovne glavne skupštine Vegetarskoga društva 20. travnja 1933. godine. Više vidi u HVD sig. 1, Zapisnik Glavne skupštine Vegetarskog Društva od 22. svibnja 1929. godine i Zapisnik VI. redovne glavne skupštine Vegetarskog društva u Zagrebu od 20. travnja 1933. godine.

${ }^{26}$ Jelisava Liza Vavra (Križevci, 1884. — Zagreb, 1946.) bila je vegetarijanka i predsjednica Jugoslavenskog teozofskog društva. O početcima teozofije više vidi: https:// www.teozofija.info/Teozofsko_gibanje/O_osnutku.htm (pristupljeno 13. 4. 2021.).

27 Dr. Ivo Hengster (Sajach, Austrija, 2. studenoga 1882. — Zagreb, svibanj 1945.) bio je pravnik, pjesnik, vegetarijanac. O dr. Hengsteru više vidi u: Krešimir BELOŠEVIĆ, "Dr. Ivo Hengster - predsjednik Hrvatskog vegetarskog društva u Zagrebu i razvoj vegetarijanstva u Hrvatskoj«, Godišnjak Njemačke narodnosne zajednice. VDG Jahrbuch 16, Osijek, 2009., 89-102 i Krešimir BELOŠEVIĆ, "Dr. Ivo Hengster — vegetarijanski pisac i urednik vegetarijanskog časopisa Vegetarizam - Glasnik Vegetarskog društva u Zagrebu“, Godišnjak Njemačke zajednice. Jahrbuch DG 22, Osijek, 2015., 111-126.

${ }^{28}$ Marko Werner, jedan od najstarijih hrvatskih vegetarijanaca, napisao je knjigu Svjetski proglas vegetaraca za svakoga i svima narodima, Zagreb, 1931. Istu knjigu izdao je i na njemačkom jeziku pod naslovom Weltaufruf der Vegetarier an jeden Einzelnen und an alle Völker 1936. godine u Zagrebu.

29 HVD, sig. 2 Pravila Vegetarskog društva iz 1928. godine. O početcima organiziranog vegetarijanstva piše dr. Ivo Hengster u tekstu "Vegetarsko društvo" I, Vegetarizam. Glasnik Vegetarskog društva u Zagrebu, Zagreb, god. 2, br. 5, 33-39.

30 Hengster, "Vegetarsko društvo" I, 34 . 
pisnika i štambilja. Nabava knjige zapisnika povjerena je predsjedniku dr. Pilaru. Na sjednici se raspravljalo i o ponudi „beogradskog liječnika glađu“ Rusa Alekseja Suvorina, koji je izrazio želju da održi predavanje u Zagrebu. ${ }^{31}$ Zaključeno je da će Vegetarsko društvo ne samo organizirati predavanje, već da će Suvorinu pomoći u organizaciji predavanja. Sam zapisnik potpisali su predsjednik dr. Pilar i tajnik Ljudevit Franković. 32

Pilar je u to vrijeme stalno aktivno prisutan u radu Vegetarskog društva. Na drugoj odborskoj sjednici, održanoj 16. listopada 1928. godine, a na kojoj su uz njega bili prisutni potpredsjednica dr. Milica Bogdanović, tajnik Ljudevit Franković i članovi Valerija Mayerhoffer, Marko Werner i Martin Friščić, te na kojoj je tajnik obavijestio prisutne da je nabavio štambilj Društva, dr. Pilar izvještava da će tek sljedeći put imati sve društvene knjige. U daljnjoj diskusiji u kojoj se raspravljalo o predavanju Alekseja Suvorina dr. Pilar je istaknuo kako ne bi želio da Društvo na početku svoga rada preuzima obveze te predložio da se prvo ispitaju eventualni troškovi vezani uz to predavanje. Tajnik Franković preuzeo je obvezu prikupljanja informacija o dvorani u Domu radničke komore, a dr. Pilar se obvezao pitati u Domu općinskih činovnika. U raspravi je dr. Pilar postavio pitanje vlasniku Menze i tajniku Frankoviću na koji način će se pokriti troškovi rada Društva u Menzi. Tajnik je izjavio kako je svjestan da Društvo nema sredstava te predlaže da ono pridonese za upotrebu prostorija kada se stanje poboljša. Izjava je prihvaćena sa zahvalnošću, te je sjednica zaključena. 33

Dr. Pilar predsjedao je i trećom sjednicom odbora Vegetarskog društva potkraj listopada u Zagrebu. Sjednici su prisustvovali potpredsjednica dr. Milica Bogdanović te članovi Valerija Mayerhoffer i starješina Marko Werner. Dr. Pilar je izvijestio prisutne da se dvorana u Domu općinskih činovnika ne može dobiti za predavanje, a tajnik Franković referirao je da se dvorana u Radničkoj komori može dobiti ako se na vrijeme utvrdi datum i svrha predavanja. Zaključeno je da bi Društvo moglo pomoći u organizaciji predavanja dr. Suvorina tako što bi pokrilo dio troškova za najam dvorane. Na sjed-

\footnotetext{
31 Aleksej Suvorin rođen je 1862. godine u Moskvi. Završio je Filozofski fakultet, a od 1886. do 1904. bio je urednik časopisa Novoe Vremja. Došao je u Kraljevinu Srba, Hrvata i Slovenaca 1920. godine. O Suvorinu više vidi u Vojislav Milovanović (ur.), Medicinski godišnjak Kraljevine Jugoslavije, Beograd, Jugoreklam K. D., 1933., str. 373-374, gdje je opisan kao nadriliječnik. Svoju metodu liječenja glađu Suvorin je opisao u više knjižica objavljenih u Beogradu i Zagrebu.

32 HVD, Zapisnik I. odborničke sjednice Vegetarskog društva nalazi se pod sig. 1 Zapisnici sjednica tijela uprave, 1928./1947.

33 HVD sig. 1, Zapisnik II. sjednice odbora Vegetarskog društva u Zagrebu od 16. listopada 1928. godine.
} 
nici je došla do izražaja europska orijentacija dr. Pilara, koji je predložio da Društvo uspostavi što brži kontakt s većim vegetarijanskim društvima u inozemstvu, te je obećao da će uz pomoć švicarskog i čehoslovačkog konzulata tražiti vezu s društvima u Švicarskoj i u Warsdorfu u Čehoslovačkoj. Na molbu tajnika Frankovića dr. Pilar je preuzeo originalna pravila Društva potvrđena od vlasti te ih pohranio u blagajni u svojem uredu. ${ }^{34}$

Osim pomoći u organizaciji dr. Pilar je pomagao rad Vegetarskog društva i na druge konkretne načine, primjerice ustupanjem prostora za održavanje sjednica. Tako se glavna skupština Društva 22. svibnja 1929. održala u njegovoj pisarnici.

Ta je sjednica važna i zato što se na njoj dr. Pilar, zbog zauzetosti odvjetničkim i javnim kulturnim radom, povukao s dužnosti predsjednika Društva. Na početku sjednice otvorio je Skupštinu i konstatirao da je u smislu članka 8. pravila Vegetarskog društva rad Skupštine zakonit. Potom se prešlo na dnevni red te je tajnik i blagajnik Franković pročitao tajnički i blagajnički izvještaj, a član Nadzornoga odbora Edo Horn izvijestio Skupštinu da su knjige uredno vođene. Predsjedatelj dr. Pilar stavio je na glasovanje odrješnicu od položaja dotadašnje uprave, koja je jednoglasno prihvaćena. Poslije prihvaćanja odrješnice dr. Pilar je prekinuo Skupštinu te su članovi tijekom slobodnog razgovora sastavljali kandidacijske liste za izbor nove uprave. Nakon provedenih izbora za predsjednika Društva, daljnji rad Skupštine nastavio se pod predsjedanjem nove predsjednice Društva Milene pl. Šišić, koja je prihvatila dužnost. Dr. Pilar je uime odstupajućeg odbora predložio da u novom odboru budu: dr. Milica Bogdanović, Ljudevit Franković, Edo Horn, Marcel Kolin, Fani de Laszowsky, 35 dr. Ivo Pilar, Martin Friščić, Mihaela Šram. Odbor Vegetarskog društva izabran je jednoglasno. Novi nadzorni odbor predložila je nova predsjednica Društva Milena Šišić, a u njemu su bili Lavoslav Zeisler, Olga Ulčakar i Vjekoslav Smetko. Nadzorni odbor Društva izabran je jednoglasno, a s obzirom na to da nije bilo drugih tema za raspravu, dr. Pilar je zaključio Skupštinu. ${ }^{36}$

\footnotetext{
${ }^{34}$ HVD sig. 1, Zapisnik III. sjednice odbora Vegetarskog društva u Zagrebu od 30. listopada 1928. godine.

35 O vegetarijanki Fani Laszowsky više vidi Krešimir BELOŠEVIĆ, "(Ne)obični detalji iz života zagrebačke vegetarijanke Jozefine Fini Laszowski», Godišnjak Njemačke zajednice. DG Jahrbuch 25, Osijek 2018., 179-192.

36 HVD sig. 1, Zapisnik glavne skupštine Vegetarskog društva od 22. svibnja 1929. godine. U tom zapisniku uz imena nekih članova upisane su adrese i brojevi telefona, pa se uz ime dr. Ive Pilara nalazi adresa njegove pisarnice, Berislaviceva ul. 8 i telefon 3043.
} 
Aktivni rad dr. Pilara za vegetarijansku ideju nastavio se i po odlasku s predsjedničke funkcije. Tako je uime predsjednice Milene Šišić javio redarstvu da će 8. lipnja 1929. u dvorani bivšeg Hrvatskog sokola predavanje o liječenju gladovanjem održati beogradski liječnik dr. Milivoj Jambrišak. Za predavanje je sjedeće mjesto stajalo 10, stajaće 5 dinara, a đaci su trebali platiti 2 dinara. 37

\section{Ostale aktivnosti dr. Ive Pilara u Vegetarskom društvu}

Bitna uloga dr. Pilara u radu Vegetarskog društva očitovala se i na druge načine. Kao što je već spomenuto, u Društvu je držao predavanja, a u radu Vegetarskog društva sudjelovao je i kao odbornik, ali i pomirbeni član. ${ }^{38}$ Dr. Pilar je iskoristio svoje diplomatske sposobnosti u rješavanju problematične situacije koja je nastala jer se Marko Werner u svojim knjigama predstavljao kao jugoslavenski starješina vegetaraca (jugoslavischer Senior der Vegetarier) i ujedinitelj teozofa i vegetaraca. U Zapisniku X. sjednice odbora Vegetarskog društva piše "... da se g. Marku Werneru dade lična zadovoljština ličnim pismom od Veg. (etarskog) društva što g. dr Ivo Pilar odma sastavlja .39

Angažiranost dr. Pilara opisana je u tajničkim izvještajima glavnih skupština. Tajnički izvještaj četvrte glavne skupštine, 28. travnja 1931. godine, posebno se bavio napredovanjem Društva i javnom propagandom na polju vegetarijanstva. Izrečena je zahvala predavačima: dr. Milici Bogdanović, dr. Desanki Ristović-Gjermanović, dr. Ivi Pilaru i dr. Ivi Hengsteru, a potonjoj dvojici i zahvala za novinske publikacije. 40

Potkraj 1932. i početkom 1933. godine uži odbor u sastavu dr. Milica Bogdanović, dr. Ivo Pilar i dr. Ivo Hengster pripremio je nova pravila Vegetarskog društva, predstavljena na Glavnoj skupštini potkraj travnja 1933. godine. 41

Dr. Pilar je surađivao s istomišljenicima i poslije šeste Glavne skupštine Vegetarskog društva. Razgovarajući s novoizabranim predsjednikom dr. Ivom Hengsterom tijekom šetnje po Zrinjevcu, pokazao je da ozbiljno shvaća probleme u radu Društva. Dr. Hengster u svojem tekstu "Vegetarsko društvo II.

\footnotetext{
37 Hengster, "Vegetarsko društvo", I, 36.

38 HVD sig. 1, Zapisnik X. sjednice odbora Vegetarskog društva u Zagrebu od 31. ožujka 1932. godine.

39 HVD sig. 1, Zapisnik X. sjednice odbora Vegetarskog društva u Zagrebu od 31. ožujka 1932. godine.

40 HVD sig. 1, Zapisnik IV. glavne skupštine Vegetarskog društva od 28. travnja 1931. godine.

${ }^{41}$ HVD sig. 1, Zapisnik VI. redovne skupštine Vegetarskog društva u Zagrebu od 20. travnja 1933.
} 
1933-1938.", u kojem opisuje povijest vegetarijanstva u Hrvatskoj, između ostalog piše o svojim razgovorima s dr. Pilarom: "Kad me je pok. dr. Pilar na Zrinjevcu pitao, kako se osjećam kao novi predsjednik, odgovorio sam pitanjem, da li čovjek može biti sretan u nesretnoj sredini. Mislio sam dakako na sredinu, koja živi samo da uživa. Tada mi se učinilo da me je naš bivši predsjednik dobro razumio, jer mu nasmiješene usne zatitraše bolnim trzajima trpkog sažaljenja. Bilo je to samo par mjeseci prije njegove tragične smrti.،42

\section{Smrt dr. Ive Pilara i sućut hrvatskih vegetarijanaca}

Dr. Ivo Pilar umro je 3. rujna 1933. godine, a u povodu njegove nenadane smrti dr. Hengster je već dan poslije sazvao izvanrednu sjednicu na koju su došli oni koje je uspio obavijestiti. Na sjednici su bili dr. Ivo Hengster, Elza Boltezar, Edo Horn, Bruno Herzl, Dragutin Preglej i Marko Werner. Na početku je dr. Hengster zamolio "prisutne da dubokim bolom u srcu odadu poštovanje pok. Dru. Ivi Pilaru, suosnivaču i prvom predsjedniku V.(egetarskog) D.(ruštva), koji je 3. o.(vog) mj.(eseca) naglo preminuo“. Predložio je da Društvo korporativno prisustvuje sprovodu 5. rujna u 11 sati dopodne iz mrtvačnice na Mirogoju, da on kao predsjednik održi govor i da se u ormarićima izvjesi cirkular ovog sadržaja: "Uprava vegetarskog društva u dubokom bolu radi nenadane smrti bivšeg prvog društvenog pretsjednika i osnivača G. odvjetnika Dr. Ive Pilara pretsjednika Sociološkog društva, poznatog javnog radnika i priznatog pobornika vegetarske ideje, saopćuje članovima V.(egetarskog) D.(ruštva) da je sahrana pokojnika sutra 5. septembra u 11 sati d(o)p.(odne) iz mrtvačnice na Mirogoju, i moli sve članove i druge vegetarijance da prisustvuju sprovodu svog milog druga. 43

Dr. Hengster je i preko novina uime Društva pozvao sve njegove članove i ostale vegetarijance da dođu na sprovod. Članovi društva odredili su svotu od 350 dinara za nabavu vijenca od poljskog cvijeća s natpisom na vrpci "Svom prvom predsjedniku, Vegetarsko društvo" te se dogovorili da se stupi u kontakt s obitelji vezano za otkup vegetarskih knjiga iz knjižnice dr. Ive Pilara. Vegetarijanci su pozvani da sudjeluju u misi zadušnici u crkvi sv. Marka evanđelista na Gornjem gradu 6. rujna u 9 sati ujutro. Zbog smrti svo-

\footnotetext{
42 Dr. Ivo Hengster, "Vegetarsko društvo", II, Vegetarizam. Glasnik Vegetarskog društva u Zagrebu, Zagreb, god. 2, br. 6-7, 41-52. Dvojica vegetarijanaca razgovarala su poslije VI. redovne glavne skupštine Vegetarskog društva 20. travnja 1933. godine na kojoj je dr. Ivo Hengster postao njegov treći predsjednik. Više vidi u HVD sig. 1, Zapisnik VI. redovne glavne skupštine Vegetarskog društva u Zagrebu od 20. travnja 1933. godine.

43 HVD sig. 1, Zapisnik vanredne sjednice Upravnog odbora Vegetarskog društva u Zagrebu od 4. rujna 1933. godine.
} 
jeg prvog predsjednika Društvo je odgodilo društveni izlet sa 10. na 17. rujna 1933. godine.

Dr. Pilar je pokopan na zagrebačkom groblju Mirogoju 5. rujna u 11 sati u obiteljskoj grobnici. Sprovodu i misi zadušnici prisustvovali su i mnogi vegetarijanci. Na prvoj odborskoj sjednici poslije smrti i pokopa dr. Ive Pilara, 7. rujna 1933. godine okupili su se članovi uprave Vegetarskog društva dr. Hengster, Gjuro Akerman, Boltezar, Horn, Preglej, Branko Savić, Miljenko Vučkić i Marko Werner. Na sjednici je predsjednik Hengster izvijestio prisutne o nenadanoj smrti i sprovodu dr. Pilara te još jedanput pročitao nadgrobni govor. Prisutni su na molbu predsjednika u znak žalosti ustali i zaželjeli vječni mir milom pokojniku. ${ }_{4}^{44}$ Odlučeno je također da će nadgrobni govor na molbu predsjednika Hrvatskoga planinarskog društva prof. Cividinija biti tiskan u časopisu Hrvatski planinar. ${ }^{45}$ Društvo će nabaviti tiskani govor za arhivu Društva. Predsjednik je zadužen da se s obitelji Pilar dogovori oko knjiga iz knjižnice dr. Pilara, a obitelji dr. Pilara Društvo će i pismeno izraziti sućut. U daljnjem radu odborske sjednice raspravljalo se i o drugim temama. Smrt dr. Pilara potaknula je, kao što je već spomenuto, članove Društva da odgode društveni izlet. Radilo se o izletu na Jalševac s predavanjem "O gladovanju", koje je trebao pripremiti član Kazimir Takač. Na sjednici je predsjednik dr. Hengster izvijestio i da ga je nenadana Pilarova smrt spriječila da na vrijeme redigira manifest Vegetarskog društva. Odborska sjednica Vegetarskog društva održana je u nazočnosti članova uprave i Društva dr. Hengstera, Pregleja, Akermana, E. Boltezar i Horna.

\section{Knjige iz knjižnice dr. Ive Pilara}

Vegetarijanci su prema dogovoru pokušali nabaviti knjige iz knjižnice dr. Ive Pilara. Predsjednik dr. Hengster je izvijestio prisutne na jednoj od sljedećih sjednica o razgovoru sa zetom dr. Pilara, dr. Tomom Jančikovićem, koji ga je obavijestio da je pokojnik oporukom ostavio znanstvene knjige Jugoslavenskoj akademiji znanosti i umjetnosti. ${ }^{46} \mathrm{U}$ povodu te oporučne odredbe

\footnotetext{
${ }^{44}$ HVD sig. 1, Zapisnik odborske sjednice Vegetarskog društva u Zagrebu od 7. rujna 1933. godine.

45 Više vidi u N. N., † Dr. Ivo Pilar, Hrvatski planinar, Zagreb, godište 29, listopad 1933., br. 10, 343-344. Vidi i Tajnički izvještaj sa Sedme redovne glavne skupštine Vegetarskog društva, HVD sig. 2, Zapisnik VII redovne glavne skupštine Vegetarskog društva od 26. travnja 1934. godine.

46 Dr. Ivo Pilar je tijekom svog života napisao dvije oporuke koje su sačuvane te objavljene u časopisu Pilar. Časopis za društvene i humanističke studije, Zagreb, 2006., god. 1, br. 1 (1), 141-144. Obje oporuke uz osnovne odredbe vezane za materijalnu ostavštinu imaju i odredbu vezanu za knjižnicu. Dr. Pilaru je to bilo važno, jer je u oba slučaja krajnji nasljednik bila Jugoslavenska akademija znanosti i umjetnosti.
} 
dr. Hengster se obratio tajniku Akademije dr. Ivanu Esihu s molbom da se reformske i vegetarske knjige iz knjižnice sortiraju. Tajnik je obećao da će službenici Knjižnice JAZU-a sortirati njegove knjige kako bi se mogle lakše pregledavati i proučavati. Odbor je zaključio da se odustaje od zaključka odborske sjednice od 4. rujna 1933. godine vezanog za nabavu knjiga dr. Pilara. ${ }^{47}$

Obitelj pokojnoga dr. Ive Pilara odgovorila je na pisanu sažalnicu Vegetarskog društva tiskanom zahvalom. Kasnijih godina hrvatski vegetarijanci su se prisjetili svojih pokojnih članova, među ostalima i dr. Pilara, u izvještajima glavnih skupština i u tekstovima objavljenim u periodičnim izdanjima. ${ }^{48}$

$$
\text { Zaključak }
$$

Dr. Ivo Pilar postao je vegetarijanac početkom 20. stoljeća zbog zdravstvenih razloga. Tijekom života svoja je osobna vegetarijanska iskustva pokušao prenijeti u teorijskom i praktičnom obliku na svoje istomišljenike. Aktivno je sudjelovao u organizaciji vegetarijanskog pokreta u Hrvatskoj po uzoru na bečke vegetarijance. Bio je prvi predsjednik Vegetarskog društva u Zagrebu, a držao je predavanja o vegetarijanskim temama i u drugim društvima. Poslije prestanka predsjedničke dužnosti sudjelovao je u radu Vegetarskog društva kao odbornik dajući korisne savjete, ali i pripremajući nova pravila Društva, pišući na temu vegetarijanstva i na različite druge načine. Poslije njegove smrti vegetarijanci su ga se prisjećali kao vjernog druga koji je živio za vegetarijansku ideju.

\section{Krešimir Belošević \\ Dr. Ivo Pilar in the Croatian historical mosaic of vegetarianism}

This paper presents new results relating to the geopolitician, writer, mountaineer, lawyer and sociologist, dr. Ivo Pilar, and his role in the history of vegetarianism in Croatia. By analyzing the preserved archival records, there have been new findings relating to the Croatian historical mosaic of vegetarianism. Dr. Pilar became a vegetarian at the beginning of the 20th century due to medical reasons. By talking to various people in a socio-political environment, he presented his view of vegetarianism all over Europe. Using the experiences he gained abroad, he actively took part in

\footnotetext{
47 O knjižnici dr. Ive Pilara više vidi u: Ivica Zvonar, "Sudbina znanstvene knjižnice dr. Ive Pilara“, Pilar. Časopis za društvene i humanističke studije, Zagreb, 2007., god. 2, br. 4 (2), 141-144. JAZU je tijekom 1934. godine primila više od 400 svezaka iz knjižnice dr. Pilara.

48 Hengster, "Vegetarsko društvo«, I, 33-39.
} 
organizing the vegetarianism movement in Zagreb, Croatia. Once the Vegetarian Society was founded in Zagreb, he was elected as its first president. Despite his many private and professional obligations, dr. Pilar held a number of lectures on vegetarianism for numerous organizations. Following his unexpected passing, Zagreb's vegetarians gathered at his funeral to pay their respects to the first president of their society.

Key words: dr. Ivo Pilar, vegetarianism, Vegetarian Society 